\title{
An investigation of attitude, motivation and anxiety levels of students studying at a faculty of tourism towards vocational English course*
}

\author{
Selda Özer ${ }^{a} \dagger$ \\ ${ }^{a}$ Nevşehir Hacı Bektaş Veli University, School of Foreign Languages, Nevşehir,50300, Turkey
}

\section{APA Citation:}

Özer, S. (2019). An investigation of attitude, motivation and anxiety levels of students studying at a faculty of tourism towards vocational English course. Journal of Language and Linguistic Studies, 15(2), 560-577.

Submission Date:12/11/2018

Acceptance Date:18/01/2019

\begin{abstract}
The aim of the study is to analyse attitude, motivation and anxiety levels of students at a state university studying at a faculty of tourism towards vocational English course. In the study, quantitative research and survey method were used. 325 students participated in the study voluntarily. Attitude Scale towards Vocational English Course, Foreign Language Classroom Anxiety Scale (FLCAS) and Attitude/Motivation Test Battery (AMTB) were used in the research to collect data. At the end of the study, the students' attitude and motivation levels towards vocational English course were at "Agree" level, and their anxiety levels were at "Slightly agree" level. Attitude, motivation and anxiety levels of students did not differ in terms of age. There was a significant difference between attitude, motivation and anxiety levels in terms of department, achievement and additional study. There was a significant difference in anxiety, while there was no significant difference in attitude and motivation levels in terms of gender. While attitude and anxiety did not differ, motivation differed in terms of tourism experience of the students.
\end{abstract}

(C) 2019 JLLS and the Authors - Published by JLLS.

Keywords: Faculty of tourism; vocational English course; attitude; motivation; anxiety.

\section{Introduction}

Departments within faculties of tourism aim to train qualified personnel for the tourism sector. Faculties of tourism in Turkey have various departments, such as tourism management, tourism and hotel management, tourism guidance, recreation management, travel management, hospitality management, food and beverage management and gastronomy and culinary arts. The first thing that comes to mind when tourism is concerned is the necessity of speaking foreign languages. Being able to use a foreign language in the sector requires proficiency in the language. Based on these requirements, vocational English courses are included in the curriculum of these departments. Students at tourism faculties are aware of the necessity and importance of this course for their professional life. Students consider this course as an opportunity to improve themselves and want to take advantage of this opportunity as much as possible (Özer, 2018; Balc1, 2016). However, attitude, motivation and anxiety as affective characteristics of students influence learning the foreign language (MacIntyre \& Gardner,

\footnotetext{
* The study was presented orally in 27th International Conference on Educational Sciences from 18th to 22nd April 2018 in Antalya.

† Selda Özer. Tel.: +90-505-253-8444

E-mail address: sozer@nevsehir.edu.tr
} 
1991; Alrabai \& Moskovsky, 2016) and this situation reveals itself in vocational English courses as in other foreign language courses.

Attitude is defined as the reactions of learners as a result of evaluating a number of ideas, objects or situations based on their beliefs and opinions (Gardner, 1985). In the literature, various studies detecting attitudes of students towards English in different educational levels reached different findings. In some studies, male students have less positive attitudes than female students (Genç \& Aydın, 2017; Özdinç Delbesoğlugil, 2013). Contrary to these findings, some studies found out that attitude levels of male students towards general English were higher than those of female students (Tetik, 2016; Kazazoğlu, 2013; Soleimani \& Hanafi, 2013). Moreover, some studies revealed that the difference was not significant in the students' attitude levels in terms of gender (Güryay, 2016, Karataş et al., 2016a; Kiz1ltan \& Atl1, 2013; Durer \& Sayar, 2013; Karabulut, 2013; Temur, 2013). A study examining the attitude levels of students towards vocational English course reached a conclusion that the difference was significant for attitudes of students in terms of gender, age, department and achievement. In other words, female students had higher attitude levels than male students, older students had higher attitude level than younger ones, the attitude levels of students in tourism departments were higher than the other departments, students at Tourism Guidance department had the highest attitude levels among the other departments, and students with higher achievement have higher attitude levels (Özer \&Y1lmaz, 2016).

Motivation is defined as the force that triggers the person in a situation and the underlying causes of this force. Motivation in learning a foreign language is regarded as the sum of students' positive attitudes towards learning a language as well as the desire and effort to achieve their goals (Gardner, 1985). In addition, success is influenced by motivation and motivation is influenced by the attitude in foreign language learning (Gardner \& Lambert, 1972). Similar to attitude, there are various studies to examine motivation levels of students in English in different educational levels in the literature, and they reached different findings. Some studies resulted with no significant difference between the motivation levels of female and male students in English (Ataman, 2017; Çekirdek, 2014; Karakış, 2014). As opposed to these findings, in other studies, it was concluded that male students' motivation levels were less than those of female students (Y1lmaz, 2013; Madran, 2006). In a study, no significant difference was found between motivation levels of students in terms of their departments (Ataman, 2017). Another finding in the literature was that the students' motivation levels did not differ according to their academic achievement (Doğan, 2009). In a study, students with no additional study differed from those studying 1-3 hours, 4-6 hours or more (Ataman, 2017). However, there was no significant difference between additional study and motivation levels of high school students (Karakış, 2014).

Anxiety is defined as the subjective feeling of nervousness, apprehension, worry, and tension related with an arousal of the autonomic nervous system (Spielberger, 1983). Littlewood (1984) argues that foreign language is taught in a non-natural way in the classroom setting and students sometimes feel weak and helpless. MacIntyre and Gardner (1989) argue that students do not begin learning a language with any anxiety; however, it resulted from negative experiences and negative thoughts and behaviors developed throughout the learning process. If a learner's anxiety is above a certain level, it brings about an important obstacle the in language learning process and affects success negatively (Littlewood, 1984). As in attitude and motivation, there are various studies to investigate anxiety levels of students in English in different educational levels in the literature, and they reached different findings. Some studies concluded that male students were less anxious than female students (Karataş et al., 2016b; Çakıc1, 2015). On the contrary, in some studies, the conclusion was that there was no significant difference in students' anxiety levels in terms of gender (Coşkun \& Taşgın, 2018; Oğuz \& Akkaş Baysal, 2015; Tunçer \& Dogan, 2015; Karakış, 2014; Özütürk \& Hürsen, 2013; Öner \& Gediklioğlu, 2007). In some studies, anxiety levels of students did not show a significant difference in terms of age (Tosun, 2018; Çakıc1, 2015). In their study, Tunçer and Doğan (2015) found no significant difference between 
the anxiety levels of university preparatory class students in terms of their department. The difference between additional study and anxiety levels of high school students was not significant (Karakış, 2014).

As a result of the literature review, it is observed that there are a lot of studies about attitude, motivation and anxiety towards general English as expected because attitude, motivation and anxiety are some of the most important factors in language learning. Positive attitudes are related to higher language achievement. Students' attitudes towards foreign language learning influence their achievement in the course and concurrently they are affected by their achievement. (Dörnyei, 1998; Gardner \& Lambert, 1972). In addition, whereas positive attitudes affect speaking skills, negative attitudes lower interest and motivation (Brown, 2007). Students with lower attitude levels towards foreign language have higher anxiety levels, and thus, they have difficulty in learning the language (Horwitz, 2001). Moreover, there is a negative relationship between motivation and anxiety; and thus, the level of motivation will decrease as the level of anxiety increases. As a result of high anxiety and low motivation levels, students fail to achieve in learning the foreign language (Maclntyre \& Gardner, 1991; Maclntyre \& Charos, 1996). However, the number of studies on attitude, motivation and anxiety towards vocational English course is limited in the literature. Özer and Yllmaz (2016) examined only attitudes of vocational college students towards vocational English course in Turkey. Motivation and anxiety were not addressed in the study. Bensoussan (2014) examined motivation and attitude levels of the students who took reading in academic English course in Israel, and revealed that achievement is in relation to motivation and attitude levels. Anxiety was not addressed in the study. Based on this limitation in the literature, the study aimed to examine the attitude, motivation and anxiety levels of the students towards vocational English course together. It is thought that examining students' attitudes, motivation and anxiety levels towards vocational English course in terms of different variables will be an important research subject by evaluating students in the context of foreign language teaching and vocational English teaching. In addition, the study will shed light on the identification of prospective tourism staff and enable to train qualified personnel for the sector. All in all, the study aims at examining the attitude, motivation and anxiety levels of the students at a faculty of tourism towards vocational English course. Specifically, the study asks the following questions:

1. What are the attitude, motivation and anxiety levels of students?

2. Do students' attitude, motivation and anxiety levels differ in terms of their gender?

their age?

their departments?

their achievement in vocational English course?

their additional study?

their tourism experience?

\section{Method}

Quantitative research design and survey methodology were conducted in the study. Survey methodology is a research model that aims to examine a situation as it exists in the nature (Karasar, 2003). The study aims at analyzing attitude, motivation and anxiety levels of students studying at a faculty of tourism in their own context. 


\subsection{Participants}

The present study was carried out in a faculty of tourism at a state university in Turkey. All students taking vocational English courses in 2016-2017 spring semester were included in the study. Vocational English course is given to the junior and senior students at the faculty, thus junior and senior students participated in the study. A total of 325 students enrolled in the faculty, and those taking the course participated in the study voluntarily and gave consent to collect data. Demographic factors of the students were given in Table 1.

Table1. Demographic features of the students

\begin{tabular}{llll}
\hline Demographic features & & f & $\%$ \\
\hline \multirow{2}{*}{ Gender } & Female & 127 & 39.1 \\
& Male & 198 & 60.9 \\
\hline \multirow{2}{*}{ Age } & 19-24 years old & 205 & 63.1 \\
& Older than 25 & 120 & 36.9 \\
\hline \multirow{3}{*}{ Department } & Tourism Management & 210 & 64.6 \\
& Tourism Guidance & 49 & 15.1 \\
& Gastronomy and Culinary Arts & 66 & 20.3 \\
\hline \multirow{3}{*}{ Achievement } & 1 low (FD-FF-DC-DD) & 47 & 14.5 \\
& 2 mid (CB-CC) & 145 & 44.6 \\
\multirow{2}{*}{ Additional study } & 3 high (AA-BA-BB) & 133 & 40.9 \\
\hline \multirow{2}{*}{ in a week } & No & 118 & 36.3 \\
& $1-2$ hours & 158 & 48.6 \\
& More than 2 hours & 49 & 15.1 \\
\hline \multirow{2}{*}{ Tourism experience } & No & 38 & 11.7 \\
& Less than1 year & 104 & 32.0 \\
& $1-3$ years & 74 & 22.8 \\
& More than 3 years & 109 & 33.5 \\
\hline \multirow{2}{*}{} & Total & 325 & 100 \\
\hline
\end{tabular}

\subsection{Instrument( $s)$}

Attitude Scale towards Vocational English Course: Attitude Scale towards Vocational English Course is a 28-item scale developed by Özer (2016), including "I think it is useful to take vocational English course no matter how hard it is". In order to determine the scale items, 98 students majoring tourism programs, and those having taken vocational English course were asked to express their feelings and thoughts about the course in 2013-2014 spring semester. The repetitive cognitive, affective and psychomotor expressions used in the compositions were selected and preliminary items were determined for the draft scale taking attitude scales in the literature into consideration. Thus, 40 items were included in the draft scale. In order to ensure the content validity of the scale, the draft scale was submitted to the opinions of an academician from the department of curriculum and instruction, an academician from the department of assessment and evaluation, and 3 lecturers of English. 12 items were omitted and the draft scale was prepared with 28 items, including 17 positive and 11 negative, for the pilot study. The scale items were also examined by the two lecturers of Turkish language for accuracy. As a result of the consultation, some items were rearranged.

The pilot study was conducted in 2014-2015 fall semester. 158 students taking vocational English course participated in the pilot study. Total item correlation coefficients ranged from .61 to .82. According to Büyüköztürk (2005), item-total correlation coefficients should be 0.30 and above. KMO coefficient was examined to check whether sample size was adequate for factor analysis and Barlett's 
test was investigated to control whether variables are distributed normally. KMO coefficient was 0.95 and Barlett's test was 0.00. If KMO is higher than 0.60 and Barlett's test is significant, factor analysis can be applied for the data (Büyüköztürk, 2005). Then, exploratory factor analysis was conducted to determine the factor loadings and construct validity. The explanatory factor analysis showed that the eigenvalues of 28 items in the scale were distributed on four factors bigger than 1, which explained $65.7 \%$ of the total variance. The contribution of the four factors to the total variance was $52.5 \%, 5.1 \%$, $4.2 \%$ and $3.7 \%$ respectively. The eigenvalues of the factors were $14.70 ; 1.43 ; 1.20$ and 1.04 respectively. Factor loadings of all the items in the scale were high in the first factor. Next, Scree Plot was analyzed and there was a rapid decrease in the first factor. When all the analyses were taken into account, the scale was considered to have one factor. In other words, the fact that factor loadings of all items in the first factor were high, that the variance explained by the first factor was significant, and that the eigenvalue of the first factor was three times higher than the eigenvalue of the second factor were evidences that the scale had one factor (Büyüköztürk, 2005). Therefore, it was concluded that the scale had a one-factor structure. Moreover, the first factor alone accounted for $52.5 \%$ of the total variance. If variance explained by the first factor is $30 \%$ and higher, the scale is considered to be acceptable for a one-factor scale (Büyüköztürk, 2005; Çokluk, Şekercioğlu \& Büyüköztürk, 2014). Cronbach Alpha reliability was estimated as 0.96 . The psychological scales with 0.70 and higher Cronbach Alpha are assessed as reliable scales (Büyüköztürk, 2005). Therefore, the scale was regarded as a reliable, valid and one-factor scale (Özer, 2016; Özer \& Y1lmaz, 2018).

For confirmatory factor analysis, 331 students taking vocational English course in 2015-2016 spring semester participated in the study. Since the scale had one factor, confirmatory factor analysis was applied to analyze one-factor structure of the scale and suitability of the model (Tabachnick and Fidell, 2007). Fit indices of the one-factor model were analyzed and chi-square was significant $(x 2=1068.43$, $\mathrm{sd}=350, x 2 / \mathrm{sd}=3.05, \mathrm{p}<0.001)$. Fit indices of the model were RMSEA $=0.08$ and $\mathrm{CFI}=0.81$. When fit indices were examined, the values were observed to be close to the ones expressed in the literature (Kline, 2005; Tabachnick and Fidell, 2007) but not at the expected level. When modification indices about the variables in the model were examined, it was observed that there were relationships between the errors of some items. Modification indices show the decrease in the chi-square value as a result of adding a particular parameter (releasing it) or new parameters (Sümer, 2000). Based on these indices, error correlations for item parceling of the same latent variable were added to the model and reanalyzed. Final confirmatory factor analysis exhibited that chi-square values were significant $(x 2=727.55, \mathrm{sd}=336$, $x 2 / \mathrm{sd}=2.17 \mathrm{p}<0.001$ ). Fit indices of the model were RMSEA=0.06, SRMR=0.06, IFI $=0.90$ and $\mathrm{CFI}=0.90$. Therefore, the results of the analyses implied that fit indices of the model were acceptable (Kline, 2005; Tabachnick and Fidell, 2007). Factor loadings and error correlations of the items were observed to be statistically significant. After the confirmatory factor analysis, Cronbach Alpha was estimated as 0.93 (Özer \& Yılmaz, 2016). In this study, reliability coefficient of Attitude Scale towards Vocational English Course was .91.

Attitude/Motivation Test Battery: Attitude/Motivation Test Battery was developed by Gardner (1985) and adapted into Turkish by Doğan (2009). A total of 34 items with four factors (Desire to Learn the Language:10 items, Motivation Intensity:10 items, Instrumental Orientation:4 items, Attitudes towards Learning the Language:10 items,) were used in the Turkish version of the scale including "Studying vocational English is important because I will need it for my career. In another study, confirmatory factor analysis was applied and chi-square $(\mathrm{x} 2=7678.53, \mathrm{sd}=505, \mathrm{x} 2 / \mathrm{d}=15.20, \mathrm{p}<.01)$ was significant. The fit indices were as follows: $\mathrm{CFI}=1, \mathrm{GFI}=.96, \mathrm{AGFI}=.95, \mathrm{RMSEA}=.097, \mathrm{RMSEA}$ CI=.095-.097 and $\mathrm{SRMR}=.076$ (Karak1ş, 2014). The students were asked to respond to the items by considering vocational English course. Reliability coefficients of the scale factors were .72 in "Desire to Learn the Language", 
.71 in "Motivation Intensity", .80 for "Instrumental Orientation", .85 in "Attitudes towards Learning the Language", and reliability coefficient of the whole scale was .92 in this study.

Foreign Language Classroom Anxiety Scale: Horwitz, Horwitz and Cope (1986) developed Foreign Language Classroom Anxiety Scale and Aydın (1999) adapted it into Turkish. The scale consisted of 33 items with three factors (Fear of Negative Evaluation: 7 items, Test Anxiety: 15 items, Communication Appreciation: 11 items), including "I start to panic when I have to speak without preparation in vocational English course". Chi-square ( $\mathrm{x} 2=3718.50, \mathrm{sd}=491, \mathrm{x} 2 / \mathrm{sd}=7.57, \mathrm{p}<.01)$ was found to be significant and fit indices were as follows: $\mathrm{CFI}=1$, GFI=.97, AGFI=.97, RMSEA=.066, RMSEA $\mathrm{CI}=.064-.068$ and $\mathrm{SRMR}=.052$ in confirmatory factor analysis for Turkish version (Karakış, 2014). The students were asked to respond to the items by considering vocational English course. Reliability coefficients of the scale factors were .81 in "Fear of Negative Evaluation", .71 in "Test Anxiety", .72 in "Communication Appreciation", and reliability coefficients of the whole scale was .88 in this study.

\subsection{Data collection procedures}

The present study was carried out with students studying at a faculty of tourism at a state university and taking vocational English course $(n=375)$ in 2016-2017 spring semester. All participants were informed that it was a voluntary survey. A total of 325 students participated in the study voluntarily.

\subsection{Data analysis}

The Statistical Package for Social Sciences (SPSS) 22.0. was used for data analysis of the current study. Maximum, minimum scores, mean and standard deviation of the three scales were determined. Prior to analyses of the data, it was checked whether the data were normally distributed. It was found out that the data showed normal distribution. Independent-Samples t-test was used for the comparison of two groups, one-way ANOVA was used for the comparison of the more than two groups. Tukey test was used to determine the source of the difference between groups. The term effect size is increasingly becoming popular throughout educational literature in the late years, and even it has been used more prevalently in recent years. Kotrlik and Williams (2003) recommended that a researcher should provide not only the statistical significance test results but also an appropriate effect size measure. According to Cohen (1988), in order to determine the effect size in t-tests, Cohen's $d$ should be calculated; and in oneway ANOVA, Cohen's $f$ should be calculated (Cohen, 1988; Kotrlik \& Williams, 2003; Özsoy \& Özsoy, 2013). As independent samples t-test and one-way ANOVA analyses were used in this study to examine mean differences, Cohen's $d$ and Cohen's $f$ were used to determine the effect size, respectively. The effect size is considered to be small if $d$ is .20, medium if $d$ is .50, and large if $d$ is .80. The effect size is considered to be small if $f$ is .10 , medium if $f$ is .25 , and large if $f$ is .40 (Cohen, 1988; Kotrlik \& Williams, 2003; Işsk, 2014).

\section{Results}

Mean, standard deviation, maximum and minimum scores for three scales were analyzed. Attitude, motivation and anxiety levels of the students were estimated and given in Table 2. 
Table 2. Attitude, motivation and anxiety levels of the students

\begin{tabular}{lcccccl}
\hline & $\mathrm{N}$ & $\mathrm{X}$ & $\mathrm{Sd}$ & Max. & Min. & Level \\
\hline Attitude & 325 & 3.51 & .65 & 5.00 & 1.21 & Agree \\
Motivation & 325 & 3.54 & .59 & 4.91 & 1.38 & Agree \\
Anxiety & 325 & 3.12 & .55 & 4.55 & 1.00 & Slightly agree \\
\hline
\end{tabular}

When Table 2 was examined, students' mean score for attitude was 3.51 and it was at "agree" level. Their mean score for motivation was 3.54 and it was at "agree" level. Finally, their mean score for anxiety was 3.12 and it was at "slightly agree" level.

Table 3 showed the result of independent samples t-test to determine whether students' attitude, motivation and anxiety levels differ in terms of their gender.

Table 3. Independent samples t-test results for attitude, motivation and anxiety in terms of gender

\begin{tabular}{|c|c|c|c|c|c|c|c|}
\hline & Gender & $\mathrm{N}$ & $X$ & $\mathrm{Sd}$ & $\mathrm{t}$ & $\mathrm{p}$ & $\begin{array}{l}\text { Effect size } \\
\text { (Cohen's d) }\end{array}$ \\
\hline \multirow{2}{*}{ Attitude } & Female & 127 & 3.49 & .64 & \multirow{2}{*}{-.415} & \multirow{2}{*}{.678} & \multirow{2}{*}{.07} \\
\hline & Male & 198 & 3.52 & .66 & & & \\
\hline \multirow{2}{*}{ Motivation } & Female & 127 & 3.57 & .54 & \multirow{2}{*}{.826} & \multirow{2}{*}{.410} & \multirow{2}{*}{.10} \\
\hline & Male & 198 & 3.52 & .62 & & & \\
\hline \multirow{2}{*}{ Anxiety } & Female & 127 & 3.20 & .52 & \multirow{2}{*}{2.165} & \multirow{2}{*}{$.031 *$} & \multirow{2}{*}{.25} \\
\hline & Male & 198 & 3.06 & .57 & & & \\
\hline
\end{tabular}

$$
{ }^{*} \mathrm{p}<.05
$$

The results indicated that there was no significant difference in the students' attitude ( $p=.678 ; p>.05)$ and motivation ( $\mathrm{p}=.410 ; \mathrm{p}>.05)$ levels. Cohen's $d$ was .07 for attitude and .10 for motivation, which implied a small effect size. However, there was a significant difference in anxiety level $(\mathrm{p}=.031 ; \mathrm{p}<.05)$. For anxiety level, female students $(X=3.20)$ had a higher mean score than male students $(X=3.06)$, and thus, female students were more anxious than male students. Nevertheless, Cohen's $d$ was .25 and had a small effect size (Table 3).

Table 4 displayed the result of independent samples t-test to determine whether students' attitude, motivation and anxiety levels differ in terms of their age.

Table 4. Independent samples t-test results for attitude, motivation and anxiety in terms of age

\begin{tabular}{|c|c|c|c|c|c|c|c|}
\hline & Age & $\mathrm{N}$ & $X$ & $\mathrm{Sd}$ & $\mathrm{t}$ & $\mathrm{p}$ & $\begin{array}{l}\text { Effect size } \\
\text { (Cohen's d) }\end{array}$ \\
\hline \multirow{2}{*}{ Attitude } & 19-24 years old & 205 & 3.53 & .66 & \multirow{2}{*}{.648} & \multirow{2}{*}{.518} & \multirow{2}{*}{.07} \\
\hline & 25 and older & 120 & 3.48 & .64 & & & \\
\hline \multirow{2}{*}{ Motivation } & 19-24 years old & 205 & 3.54 & .59 & \multirow{2}{*}{-.127} & \multirow{2}{*}{.899} & \multirow{2}{*}{.01} \\
\hline & 25 and older & 120 & 3.54 & .59 & & & \\
\hline \multirow{2}{*}{ Anxiety } & 19-24 years old & 205 & 3.12 & .54 & \multirow{2}{*}{.130} & \multirow{2}{*}{.896} & \multirow{2}{*}{.01} \\
\hline & 25 and older & 120 & 3.11 & .57 & & & \\
\hline
\end{tabular}


Table 4 indicated that there was no significant difference in attitude $(\mathrm{p}=.518 ; \mathrm{p}>.05)$, motivation $(\mathrm{p}=.899 ; \mathrm{p}>.05)$ and anxiety $(\mathrm{p}=.896 ; \mathrm{p}>.05)$ levels of students in terms of age. Cohen's $d$ was .07 for attitude, .01 for motivation and anxiety and the effect size was quite small for all of them.

Table 5 represented the result of one-way ANOVA to determine whether students' attitude, motivation and anxiety levels differ in terms of their department.

Table 5. One-way ANOVA results for attitude, motivation and anxiety in terms of department

\begin{tabular}{|c|c|c|c|c|c|c|c|c|}
\hline & Department & $\begin{array}{l}\text { Sum of } \\
\text { squares }\end{array}$ & df & $\begin{array}{l}\text { Mean } \\
\text { square }\end{array}$ & $\mathrm{F}$ & $\mathrm{p}$ & $\begin{array}{l}\text { Significant } \\
\text { difference } \\
\text { (Tukey) }\end{array}$ & $\begin{array}{l}\text { Effect size } \\
\text { (Cohen's f) }\end{array}$ \\
\hline \multirow{5}{*}{ Attitude } & Between & 22.950 & 2 & 11.475 & & & \multirow{5}{*}{$\begin{array}{l}\text { T.M.<T.G. } \\
\text { T.M.<G.C.A. }\end{array}$} & \multirow{5}{*}{.44} \\
\hline & groups & & & & & & & \\
\hline & Within & 116.044 & 322 & .360 & 31.841 & $.000 *$ & & \\
\hline & groups & & & & & & & \\
\hline & Total & 138.994 & 324 & & & & & \\
\hline \multirow{3}{*}{ Motivation } & Between & 12.286 & 2 & 6.143 & & & \multirow{3}{*}{$\begin{array}{c}\text { T.M.<T.G. } \\
\text { T.M.<G.C.A. }\end{array}$} & \multirow{3}{*}{.34} \\
\hline & $\begin{array}{l}\text { groups } \\
\text { Within } \\
\text { groups }\end{array}$ & 102.275 & 322 & .318 & 19.341 & $.000 *$ & & \\
\hline & Total & 114.562 & 324 & & & & & \\
\hline \multirow{3}{*}{ Anxiety } & $\begin{array}{l}\text { Between } \\
\text { groups }\end{array}$ & 1.991 & 2 & .996 & & & & \multirow{3}{*}{.01} \\
\hline & $\begin{array}{l}\text { Within } \\
\text { groups }\end{array}$ & 99.282 & 322 & .308 & 3.229 & $.041 *$ & T.M.>T.G. & \\
\hline & Total & 101.273 & 324 & & & & & \\
\hline
\end{tabular}

$* \mathrm{p}<.05$

As seen in Table 5, there was a significant difference in attitude ( $\mathrm{p}=.000 ; \mathrm{p}<.05)$, motivation ( $\mathrm{p}=.000$; $\mathrm{p}<.05)$ and anxiety $(\mathrm{p}=.041 ; \mathrm{p}<.05)$ levels of the students in terms of their departments. As a result of Tukey analysis for attitude, the difference was between Tourism Management $(\mathrm{X}=3.31, \mathrm{Sd}=.63)$ and Tourism Guidance $(X=3.94 ; \mathrm{Sd}=.44)$ and Gastronomy and Culinary Arts $(\mathrm{X}=3.80 ; \mathrm{Sd}=.56)$. In addition, Cohen's $f$ was .41 and had a large effect size. Similarly, for motivation the difference was between Tourism Management $(X=3.40, \mathrm{Sd}=.55)$ and Tourism Guidance $(X=3.90 ; \mathrm{Sd}=.59)$ and Gastronomy and Culinary Arts $(\mathrm{X}=3.71 ; \mathrm{Sd}=.55)$. Cohen's $f$ was .34 and effect size was medium. For anxiety, the difference was only between Tourism Management $(X=3.17, S d=.54)$ and Tourism Guidance $(X=2.95$; $\mathrm{Sd}=.64$ ). Cohen's $f$ was .01 , which implied that the effect size is quite small. Students of Tourism Guidance and Gastronomy and Culinary Arts had significantly higher attitude and motivation levels than students of Tourism Management. Moreover, students of Tourism Management were more anxious than students of Tourism Guidance.

The result of one-way ANOVA to determine whether students' attitude, motivation and anxiety levels differ in terms of their achievement was shown in Table 6.

Table 6. One-way ANOVA results for attitude, motivation and anxiety in terms of achievement

\begin{tabular}{|c|c|c|c|c|c|c|c|c|}
\hline & Achievement & $\begin{array}{l}\text { Sum of } \\
\text { squares }\end{array}$ & df & $\begin{array}{l}\text { Mean } \\
\text { square }\end{array}$ & $\mathrm{F}$ & $\mathrm{p}$ & $\begin{array}{l}\text { Significant } \\
\text { difference } \\
\text { (Tukey) }\end{array}$ & $\begin{array}{l}\text { Effect size } \\
\text { (Cohen's } f \text { ) }\end{array}$ \\
\hline \multirow{3}{*}{ Attitude } & Between & 20.362 & 2 & 10,181 & \multirow{3}{*}{27,635} & \multirow{3}{*}{$.000 *$} & $1<2$ & \multirow{3}{*}{.41} \\
\hline & groups & & 272 & \multirow{2}{*}{.368} & & & $1<3$ & \\
\hline & $\begin{array}{l}\text { Within groups } \\
\text { Total }\end{array}$ & $\begin{array}{l}118.632 \\
138.994\end{array}$ & $\begin{array}{l}322 \\
324\end{array}$ & & & & $2<3$ & \\
\hline
\end{tabular}




\begin{tabular}{llccccccc}
\hline \multirow{5}{*}{ Motivation } & Between & 9.787 & 2 & 4.894 & & & $1<2$ \\
& groups & & & & 15.039 & $.000^{*}$ & $1<3$ & .30 \\
& Within groups & 104.775 & 322 & .325 & & & $2<3$ & \\
& Total & 114.562 & 324 & & & & & $1>2$ \\
\multirow{5}{*}{ Anxiety } & Between & 3.951 & 2 & 1.976 & & & $1>3$ & .20 \\
& groups & & & & \multirow{2}{*}{6.536} & $.002 *$ & $2>3$ & \\
& Within groups & 97.322 & 322 & .302 & & & & \\
& Total & 101.273 & 324 & & & & & \\
\hline
\end{tabular}

$* \mathrm{p}<.05$

As indicated in Table 6 , there was a significant difference in attitude $(\mathrm{p}=.000 ; \mathrm{p}<.05)$, motivation $(\mathrm{p}=.000 ; \mathrm{p}<.05)$ and anxiety $(\mathrm{p}=.002 ; \mathrm{p}<.05)$ levels of the students in terms of their achievement. As a result of Tukey analysis for attitude, the difference was between students with low achievement $(X=2.96 ; \mathrm{Sd}=.73)$ and those with mid achievement $(\mathrm{X}=3.49 ; \mathrm{Sd}=.53)$ and those with high achievement $(\mathrm{X}=3.72 ; \mathrm{Sd}=.63)$. Moreover, there was a difference between students with mid achievement $(X=3.49$; $\mathrm{Sd}=.53)$ and those with high achievement $(\mathrm{X}=3.72 ; \mathrm{Sd}=.63)$. Cohen's $f$ was .41 , which implied that the effect size was large. Similarly, for motivation, the difference was between students with low achievement $(X=3.21 ; \mathrm{Sd}=.53)$ and those with mid achievement $(X=3.48 ; \mathrm{Sd}=.53)$ and those with high achievement $(\mathrm{X}=3.72 ; \mathrm{Sd}=.61)$. In addition, there was a difference between students with mid achievement $(X=3.48 ; \mathrm{Sd}=.53)$ and those with high achievement $(\mathrm{X}=3.72 ; \mathrm{Sd}=.61)$. Cohen's $f$ was .30, which implied a medium effect size. When it came to anxiety, the difference was between students with low achievement $(\mathrm{X}=3.24 ; \mathrm{Sd}=.47)$ and those with mid achievement $(\mathrm{X}=3.19 ; \mathrm{Sd}=.53)$ and those with high achievement $(X=2.98 ; \mathrm{Sd}=.58)$. In addition, there was a difference between students with mid achievement $(X=3.19 ; \mathrm{Sd}=.53)$ and those with high achievement $(\mathrm{X}=2.98 ; \mathrm{Sd}=.58)$. Cohen's $f$ was .20, which implied a small effect size. The findings inferred that students with high achievement had higher attitude and motivation levels and lower anxiety levels than those with lower achievement.

Table 7 showed the result of one-way ANOVA to determine whether students' attitude, motivation and anxiety levels differ in terms of their additional study.

Table 7. One-way ANOVA results for attitude, motivation and anxiety in terms of additional study

\begin{tabular}{|c|c|c|c|c|c|c|c|c|}
\hline & $\begin{array}{l}\text { Additional study } \\
\text { in a week }\end{array}$ & $\begin{array}{l}\text { Sum of } \\
\text { squares }\end{array}$ & df & $\begin{array}{l}\text { Mean } \\
\text { square }\end{array}$ & $\mathrm{F}$ & $\mathrm{p}$ & $\begin{array}{l}\text { Significant } \\
\text { difference } \\
\text { (Tukey) }\end{array}$ & $\begin{array}{l}\text { Effect size } \\
\text { (Cohen's } f \text { ) }\end{array}$ \\
\hline \multirow{3}{*}{ Attitude } & Between groups & 6.937 & 2 & 3.468 & \multirow{3}{*}{8.457} & \multirow{3}{*}{$.000 *$} & \multirow{3}{*}{$\begin{array}{l}1<2 \\
1<3\end{array}$} & \multirow{3}{*}{.22} \\
\hline & Within groups & 132.057 & 322 & .410 & & & & \\
\hline & Total & 138.994 & 324 & & & & & \\
\hline \multirow{3}{*}{ Motivation } & Between groups & 5.561 & 2 & 2.781 & \multirow{3}{*}{8.214} & \multirow{3}{*}{$.000 *$} & \multirow{3}{*}{$1<2$} & \multirow{3}{*}{.22} \\
\hline & Within groups & 109.000 & 322 & .339 & & & & \\
\hline & Total & 114.562 & 324 & & & & & \\
\hline \multirow{3}{*}{ Anxiety } & Between groups & 2.093 & 2 & 1.046 & & & & \multirow{3}{*}{.14} \\
\hline & Within groups & 99.181 & 322 & .308 & 3.397 & $.035 *$ & $2>3$ & \\
\hline & Total & 101.273 & 324 & & & & & \\
\hline
\end{tabular}

$* \mathrm{p}<.05$

As seen in Table 7, there was a significant difference in attitude $(\mathrm{p}=.000 ; \mathrm{p}<.05)$, motivation $(\mathrm{p}=.000$; $\mathrm{p}<.05)$ and anxiety $(\mathrm{p}=.035 ; \mathrm{p}<.05)$ levels of the students in terms of their additional study in a week. As a result of Tukey analysis for attitude, the difference was between students with no additional study $(\mathrm{X}=3.32 ; \mathrm{Sd}=.61)$ and those studying $1-2$ hours $(\mathrm{X}=3.61 ; \mathrm{Sd}=.64)$ and those studying more than 2 hours $(\mathrm{X}=3.64 ; \mathrm{Sd}=.66)$. For motivation, the difference was between students with no additional study $(X=3.37 ; \mathrm{Sd}=.51)$ and those studying $1-2$ hours $(X=3.66 ; \mathrm{Sd}=.61)$. For both attitude and motivation, Cohen's $f$ was .22 and effect size was nearly medium. For anxiety, the difference was between students 
studying 1-2 hours $(X=3.15 ; \mathrm{Sd}=.54)$ and those studying more than 2 hours $(X=2.93 ; \mathrm{Sd}=.61)$. Cohen's $f$ was .14, which implied a small effect size. The findings reflected that students with no additional study had lower attitude and motivation levels and higher anxiety levels than those with additional study.

Table 8 displayed the result of one-way ANOVA to determine whether students' attitude, motivation and anxiety levels differ in terms of their tourism experience.

Table 8. One-way ANOVA results for attitude, motivation and anxiety in terms of tourism experience

\begin{tabular}{|c|c|c|c|c|c|c|c|c|}
\hline & $\begin{array}{l}\text { Tourism } \\
\text { Experience }\end{array}$ & $\begin{array}{l}\text { Sum of } \\
\text { squares }\end{array}$ & df & $\begin{array}{l}\text { Mean } \\
\text { square }\end{array}$ & $\mathrm{F}$ & $\mathrm{p}$ & $\begin{array}{l}\text { Significant } \\
\text { difference } \\
\text { (Tukey) }\end{array}$ & $\begin{array}{l}\text { Effect size } \\
\text { (Cohen's } f \text { ) }\end{array}$ \\
\hline \multirow{3}{*}{ Attitude } & $\begin{array}{l}\text { Between } \\
\text { groups }\end{array}$ & 2.712 & 3 & 904 & \multirow{3}{*}{2.129} & \multirow{3}{*}{.096} & \multirow{3}{*}{ - } & \multirow{3}{*}{.14} \\
\hline & Within groups & 136.282 & 321 & .425 & & & & \\
\hline & Total & 138.994 & 324 & & & & & \\
\hline \multirow{3}{*}{ Motivation } & $\begin{array}{l}\text { Between } \\
\text { groups }\end{array}$ & 3.710 & 3 & & \multirow{3}{*}{3.582} & \multirow{3}{*}{$.014^{*}$} & \multirow{3}{*}{$\begin{array}{l}1>3 \\
1>4\end{array}$} & \multirow{3}{*}{.18} \\
\hline & Within groups & 110.851 & 321 & .345 & & & & \\
\hline & Total & 114.562 & 324 & & & & & \\
\hline \multirow{3}{*}{ Anxiety } & $\begin{array}{l}\text { Between } \\
\text { groups }\end{array}$ & 1.834 & 3 & .611 & \multirow{3}{*}{1.974} & \multirow{3}{*}{.118} & \multirow{3}{*}{ - } & \multirow{3}{*}{.99} \\
\hline & Within groups & 99.439 & 321 & .310 & & & & \\
\hline & Total & 101.273 & 324 & & & & & \\
\hline
\end{tabular}

$* \mathrm{p}<.05$

The results indicated that there was no significant difference in attitude $(\mathrm{p}=.096 ; \mathrm{p}<.05)$, and anxiety $(\mathrm{p}=.118 ; \mathrm{p}<.05)$; however, there was a significant difference in motivation $(\mathrm{p}=.014 ; \mathrm{p}<.05)$ in terms of tourism experience. While Cohen's $f$ was .14 and effect size was small for attitude, Cohen's $f$ was .99 and had a large effect size for anxiety. As a result of Tukey analysis for motivation, the difference was between students with no tourism experience $(X=3.79 ; \mathrm{Sd}=.58)$ and those with 1-3 years $(X=3.46$; $\mathrm{Sd}=.65)$ and those with more than 3 years $(\mathrm{X}=3.46$; $\mathrm{Sd}=.57)$. Cohen's $f$ was .18 and effect size was small. Students with no tourism experience were more motivated than those with tourism experience (Table 8).

\section{Discussion}

The present study focused on attitude, motivation and anxiety levels of students majoring tourism at a faculty of tourism towards vocational English course. Students' mean score for attitude was 3.51 and it was at "agree" level. Their mean score for motivation was 3.54 and it was at "agree" level. Their mean score for anxiety was 3.12 and it was at "slightly agree" level. These finding are consistent with the literature (Alrabai \& Moskovsky, 2016; Çakıc1, 2015; Liu \& Chen, 2015; Hişmanoğlu, 2013; Sahabani, 2012; Arnaiz ve Guillén, 2012; Pineda, 2011; Hashwani, 2008). It can be concluded from the findings that students have positive attitude towards vocational English course and they are quite motivated but they are still anxious. Anxiety level is predicted to decrease as attitude and motivation levels are high. This may result from the previous experiences of students in their academic life as in general English courses are full of grammatical rules and they may have been bored of the rules. Besides, as the participants of the study include junior and senior students, their level of anxiety to find a job may have increased, which may have resulted in the increased anxiety level for vocational English course, as Coşkun and Taşgın (2018) suggested. 
The study resulted that there was no significant difference in the students' attitude levels in terms of gender. There are similar results in the literature (Güryay, 2016; Karataş et al., 2016a; Kızıltan \& Atl1, 2013; Durer \& Sayar, 2013; Karabulut, 2013; Temur, 2013) about general English. However, in another study, it was concluded that there was a significant difference between attitudes of students at associate degree at higher education towards vocational English course in terms of gender and male students had lower attitude levels than female students (Özer \& Yllmaz, 2016). In addition, there are studies in parallel with this result for general English (Genç \& Aydın, 2017; Özdinç Delbesoğlugil, 2013; Ghazvini \&Khajehpour, 2011). On the other hand, some studies found out that attitude levels of male students towards general English were higher than those of female students (Tetik, 2016; Kazazoğlu, 2013; Soleimani \& Hanafi, 2013; Abidin et al., 2012).

Another finding was that there was no significant difference in students' motivation levels in terms of gender. Even though not directly for vocational English course, there are some studies in the literature that resulted no significant difference between the motivation levels of male and female students in English conducted with university preparatory class students (Ataman, 2017; Çekirdek, 2014) and high school students (Karakış, 2014). As opposed to these findings, in other studies conducted with high school students (Y1lmaz, 2013) and university preparatory class students (Madran, 2006), it was concluded that motivation levels of male students in English were lower than those of female students. In their study, Ghazvini and Khajehpour (2011) found out that male students are motivated more instrumentally but female students were motivated more integratively.

The study reached the conclusion that male students were less anxious than female students. The finding is consistent with some studies in the literature (Hişmanoğlu, 2013; Arnaiz ve Guillén, 2012; Mesri, 2012). Besides, Çakıcı (2015)'s study carried out with prospective English teachers and Karataş et al. (2016b)'s study conducted with university preparatory class students had similar results. As the cause, Çakıc1 (2015) suggested that female students intensely have and experience fears of communication, being tested and evaluated negatively while male students are more confident in dealing with stress and speaking in foreign languages. Contrary to these findings, in some studies held with high school students (Oğuz \& Akkaş Baysal, 2015; Karakış, 2014; Öner \& Gediklioğlu, 2007), with university preparatory class students (Tunçer \& Dogan, 2015) and with undergraduate students (Coşkun \& Taşgın, 2018; Özütürk \& Hürsen, 2013; Wang, 2011; Wang, 2010; French \& Richards, 1990), there was no significant difference in students' anxiety levels in terms of gender. In some other studies, male students are found to be more anxious than female students (Nyikos, 1990; Kitano, 2001, Karabey, 2011; Er, 2011; Cui, 2011; Aydemir, 2011).

It was found in the study that the students' attitude, motivation and anxiety levels did not differ in terms of age. However, another study found out that there was a significant difference between the attitude levels of the associate degree students towards vocational English course and the older students had a higher attitude level (Özer \& Y1lmaz, 2016). Parallel with the finding of the study, in other studies about anxiety conducted with English teacher candidates (Çakıc1, 2015) and students of English Language and Literature department (Tosun, 2018), anxiety levels of students did not reveal a significant difference in terms of age. On the other hand, in some studies younger students were found to be more anxious (Hişmanoğlu, 2013; MacIntyre, Baker, Clement, Donovan, 2002), and in some studies older students were found to be more anxious (Donovan \& MacIntyre, 2005). As the students get older, their vocabulary and language proficiency increase, they are aware of their learning strategies and styles and they can use them effectively in learning, and they realize their deficiencies and they try to overcome them (Çakıc1, 2015). Therefore, it is expected that anxiety levels will decrease by increasing selfconfidence, attitude and motivation levels (Çakıc1, 2015). Nevertheless, the finding obtained in this study is that attitude, motivation and anxiety levels of students do not change in terms of age. This 
finding can be paraphrased that students convey their affective characteristics for English course to vocational English course when it comes to anxiety in learning a language.

The study revealed a significant difference between attitude levels of students in terms of department. The difference was between Tourism Management and Tourism Guidance and Gastronomy and Culinary Arts in favor of Tourism Guidance and Gastronomy and Culinary Arts. Similarly, in another study carried out with vocational college students, attitude towards vocational English course differed significantly in terms of department, the attitude levels of students in tourism departments were higher than the other students, Tourism Guidance department had the highest attitude levels among these departments (Özer \& Y1lmaz, 2016).The finding was the same for motivation. However, in a study conducted with university preparatory class students, no significant difference was found between motivation levels of students in terms of department (Ataman, 2017). The study also found out that anxiety levels of students differed significantly in terms of their department. The difference was between Tourism Management and Tourism Guidance in favor of Tourism Management. On the other hand, in the study by Tunçer and Doğan (2015), no significant difference was found between the anxiety levels of university preparatory class students in terms of their department. In the light of these findings, students of Tourism Guidance and Gastronomy and Culinary Arts have significantly higher attitude and motivation levels than students of Tourism Management, and students of Tourism Management are more anxious than students of Tourism Guidance. As mentioned before, when attitude and motivation levels increase, anxiety level is anticipated to decrease. Consequently, the findings of the study are consistent in its own right.

The study had the finding that there was a significant difference in attitude, motivation and anxiety levels of students in terms of their achievement. For attitude, the difference was between students with low achievement and those with mid achievement and those with high achievement. Moreover, there was a difference between students with mid achievement and those with high achievement. In parallel with this finding, attitude levels of vocational college students towards vocational English course showed a significant difference in terms of achievement (Özer \&Yılmaz, 2016). The finding was the same for motivation. Nonetheless, in another study conducted with university preparatory class students, it was concluded that the students' motivation levels did not differ according to their academic achievement (Doğan, 2009). For anxiety, the difference was between students with low achievement and those with mid achievement and those with high achievement. Moreover, there was a difference between students with mid achievement and those with high achievement. The findings inferred that students with high achievement had higher attitude and motivation levels and lower anxiety levels than those with lower achievement. The finding also indicates that the higher achievement the students have, the higher their attitude and motivation levels they get and the less they are anxious.

The study reached a finding that there was a significant difference in attitude, motivation and anxiety levels of students in terms of their additional study in a week. For attitude, the difference was between students with no additional study and those studying 1-2 hours and those studying more than 2 hours. For motivation, the difference was between students with no additional study and those studying 1-2 hours. For anxiety, the difference was between students studying 1-2 hours and those studying more than 2 hours. The findings reflected that students with no additional study had lower attitude and motivation levels and higher anxiety levels than those with additional study. Likewise, in a study conducted with university preparatory class students, for motivation, it was explored that students with no additional study differed from those studying 1-3 hours, 4-6 hours or more (Ataman, 2017). Yet, in a different study, additional study did not make a significant difference for motivation and anxiety levels of high school students (Karakış, 2014).

The last finding of the study was that there was no significant difference in attitude and anxiety; however, there was a difference in motivation in terms of tourism experience. For motivation, the 
difference was between students with no tourism experience and those with 1-3 years and those with more than 3 years. Students with no tourism experience were more motivated than those with tourism experience. The finding can be interpreted that this situation is due to the fact that the students working in tourism believe that they have already mastered in English and they have had a command of English in communication thanks to their experiences, thus they think that they will achieve in the course and it is just a course to be taken.

\section{Conclusions}

The study revealed the students' mean score for attitude and motivation were at "agree" level and their mean score for anxiety was at "slightly agree" level. There was no significant difference in the students' attitude and motivation levels in terms of gender. However, female students were more anxious than male students. The students' attitude, motivation and anxiety levels did not differ in terms of age. There was a significant difference in attitude, motivation and anxiety levels of students in terms of department and students of Tourism Guidance had the highest attitude and motivation levels and the lowest anxiety levels. The study found out that there was a significant difference in attitude, motivation and anxiety levels of students in terms of their achievement and students with high achievement had the highest attitude and motivation levels and the lowest anxiety levels. The study concluded that there was a significant difference in attitude, motivation and anxiety levels of students in terms of their additional study in a week and students with additional study had higher attitude and motivation levels and lower anxiety levels. The last finding of the study was that there was no significant difference in attitude and anxiety; however, there was a difference in motivation in terms of tourism experience and students with no tourism experience were more motivated than those with tourism experience.

The results of the study have important implications for educators and students. Attitude and motivation levels of students of Tourism Management towards vocational English course are lower than the other departments. In order to increase attitude and motivation levels of these students, it should be frequently reminded that learning English serves them to find a better job, and English is as a means that will facilitate their lives, improve their quality of life and their dignity in society rather than an obstacle that needs to be overcome to get a diploma. In order to motivate students to participate in courses, at the warm-up and transition stages, teachers and instructors of English should inform students about the aim of the unit, and how and where they will use it, which will lead to higher levels of interest. In addition, students can be encouraged by informing them about and participate in activities such as student exchange programs, youth programs and various projects which enable them to go abroad. Various the activities, tasks, and materials can help to avoid boredom and anxiety, and increase students' interest levels. Cooperative learning rather than competitive will help anxious students to increase selfconfidence. As the anxiety levels of students will decrease when they have high attitude and motivation levels, all attempts for this purpose will also provide the students to be more successful in vocational English course.

The study is limited to the measurement tools used in the research. The study is also limited to students at a faculty of tourism and taking vocational English course. For further studies, attitude, motivation and anxiety levels of students at other faculties at tertiary education towards vocational English course may be analyzed and compared with the findings of the current study. Based on the finding that male students are less anxious than female students, the reasons for this situation can be investigated in depth by a qualitative research and solutions can be suggested. 


\section{Acknowledgements}

I would like to thank the students at the faculty of tourism at Nevşehir Hacı Bektaş Veli University where the study was carried out.

\section{References}

Abidin, M. J. Z., Pour-Mohammadi, M., \& Alzwari, H. (2012). EFL students' attitudes towards learning English language: The case of Libyan secondary school students. Asian Social Science, $8(2), 119-134$.

Alrabai, F., \& Moskovsky, C. (2016). The relationship between learners' affective variables and second language achievement. Arab World English Journal, 7(2), 77-103.

Arnaiz, P., \& Gulien, F. (2012). Foreign language anxiety in a Spanish university setting: Interpersonal differences. Revista de Psicodidáctica, 17(1), 5-26.

Ataman, O. (2017). Üniversite hazırlık sınıfi ögrencilerinin İngilizce öğrenmeye yönelik motivasyon düzeyleri ve tutumları ile hazırlı sınıf başarı puanları arasındaki ilişki. Unpublished master's thesis, Sakarya University, Sakarya, Turkey.

Aydemir, O. (2011). A study on the changes in the foreign language anxiety levels experienced by the students of the preparatory school at Gazi university during an academic year. Unpublished master's thesis, Gazi University, Ankara, Turkey.

Aydın, B. (1999). Konuşma ve yazma derslerinde yabancı dil öğrenimindeki kaygı nedenleri. Unpublished doctoral dissertation, Anadolu Üniversitesi, Eskişehir, Turkey.

Balcı, U. (2016). Turizm lisans öğrencilerinin dil eğitimi ile ilgili sorunları ve çözüm önerileri. The Journal of Academic Social Science Studies, 50, 93-100.

Bensoussan, M. (2014). Motivation and English language learning in a multicultural university context. Journal of Multilingual and Multicultural Development, 36(4), 423-440.

Brown, H. D. (2007). Principles of language learning and teaching. White Plains, NY: Longman.

Büyüköztürk, Ş. (2005). Sosyal bilimler için veri analizi el kitabı: İstatistik, araştırma deseni, SPSS uygulamaları ve yorum (5th ed.). Ankara: Pegem A Yayınc1l1k.

Cui, J. (2011). Research on high school students' English learning anxiety. Journal of Language Teaching and Research, 2(4), 875-880.

Çakıcı, D. (2015). Öğretmen adaylarının yabancı dil kaygısı. International Journal of Languages' Education and Teaching, 8, 495-507.

Çekirdek, G. (2014). Hazırlık sınıfı öğrencilerinin Ingilizce başarılarını etkileyen bazı faktörlerin incelenmesi. Unpublished master's thesis, Eskişehir Osmangazi University, Eskişehir, Turkey.

Çokluk, Ö., Şekercioğlu, G., \& Büyüköztürk, Ş. (2014). Sosyal bilimler için çok değişkenli istatistik: SPSS ve LISREL uygulamaları (3th ed.). Ankara: Pegem Yayıncılık.

Cohen, J. (1988). Statistical power analysis for the behavioral sciences (2nd ed.). Hillsdale, NJ: Erlbaum.

Coşkun, G., \& Taşgın, A. (2018). An investigation of anxiety and attitudes of university students towards English courses. Journal of Language and Linguistic Studies, 14(2), 135-153. 
Doğan, Ö. (2009). İngilizce hazırlık okuyan öğrencilerin motivasyon düzeyleri. Unpublished master's thesis, Eskişehir Osmangazi University, Eskişehir, Turkey.

Donovan, L. A., \& MacIntyre, P. D. (2005). Age and sex differences in willingness to communicate, communication apprehension and self-perceived competence. Communication Research Reports, 21, 420-427.

Dörnyei, Z. (1998). Motivation in second and foreign language learning. Language Teaching, 31,117-135.

Durer, Z.S., \& Sayar, E. (2013). An analysis of Turkish students' attitudes towards English in speaking classes: Voice your thoughts. Procedia-Social and Behavioral Sciences, 70, 1574-1579.

Er, S. S. (2011). A study of the effect of anxiety and beliefs on the foreign language success of the students who study at Anatolian high schools. Unpublished doctoral dissertation, Ankara University, Ankara, Turkey.

French, C., \& Richards, A. (1990). The relationship between handedness, anxiety and questionnaire response patterns. British Journal of Psychology, 81(1), 57-62.

Gardner, R. C., \& Lambert, W. E. (1972). Attitudes and motivation in second-language learning. Massachusets: Newbury House Publishers.

Gardner, R.C. (1985). Social psychology and language learning: The role of attitude and motivation. London: Edward Arnold.

Genç, Z. S., \& Aydın, F. (2017). An analysis of learners' motivation and attitudes towards learning English language at tertiary level in Turkish EFL context. English Language Teaching, 10(4), 35-44.

Ghazvini, S. D., \& Khajehpour, M. (2011). Attitudes and motivation in learning English as second language in high school students. Procedia-Social and Behavioral Sciences, 15, 1209-1213.

Güryay, B. (2016). Individual variables, attitudes towards English and being a teacher: A study on prospective teachers of English. International Journal of Psychology and Educational Studies, 3(2), 14-23.

Hashwani, M. S. (2008). Students' attitudes, motivation and anxiety towards English language learning. Journal of Research and Reflections in Education, 2(2), 121-144.

Hişmanoğlu, M. (2013). Foreign language anxiety of English language teacher candidates: A sample from Turkey. Procedia-Social and Behavioral Science, 93, 930-937.

Horwitz, E. K. (2001). Language anxiety and achievement. Annual Review of Applied Linguistics, 21, 112-126.

Horwitz, E. K., Horwitz, M. B., \& Cope, J. (1986). Foreign language classroom anxiety. The Modern Language Journal, 70(2), 125-132.

Işı, İ. (2014). Yokluk hipotezi anlamlılık testi ve etki büyüklüğü tartışmalarının psikoloji araştırmalrına yansıması. Eleştirel Psikoloji Bülteni, 5, 55-80.

Karabey, M. (2011). Foreign language classroom anxiety of preparatory class students at Atatürk University. Unpublished master's thesis, Atatürk University, Erzurum, Turkey.

Karabulut, H. (2013). Attitudes towards learning English and English language. Unpublished master's thesis, Çağ University, Mersin, Turkey.

Karakış, Ö. (2014). Lise ögrencilerinin İngilizce dersine yönelik kaygıları, motivasyonları öz-yeterlik algıları ve Ingilizce ders başarıları arasındaki ilişki. Unpublished doctoral dissertation, Abant İzzet Baysal University, Bolu, Turkey.

Karasar, N. (2003). Bilimsel araştırma yöntemleri. (12.Baskı). Ankara: Nobel Yayın Dağıtım. 
Karataş, H., Alçı, B., Bademcioğlu, M., \& Ergin, A. (2016a). Examining university students' attitudes towards learning English using different variables. The International Journal of Educational Researchers, 7(2), 12-20.

Karataş, H., Alçı, B., Bademcioğlu, M., \& Ergin, A. (2016b). An investigation into university students' foreign language speaking anxiety. Procedia-Social and Behavioral Sciences, 232, 382-388.

Kazazoğlu, S. (2013). Türkçe ve İngilizce derslerine yönelik tutumun akademik başarıya etkisi. Eğitim ve Bilim, 38(170), 294-307.

Kizıltan, N., \& Atl1, I. (2013). Turkish young language learners' attitudes towards English. Hacettepe Üniversitesi Ĕ̆itim Fakültesi Dergisi, 28(2), 266-278.

Kitano, K. (2001). Anxiety in the college Japanese language classroom. The Modern Language Journal, 85(4), 517-566.

Kline, R. B. (2005). Principles and practice of structural equation modeling. NY: Guilford Publications, Inc.

Kotrlik, J. W., \& Williams, H. A. (2003). The incorporation of effect size in information technology, learning, and performance research. Information Technology, Learning, and Performance Journal, 21(1), 1-7.

Littlewood, W. (1984). Foreign and second language learning: Language acquisition research and its implications for the classroom. Cambridge: CUP.

Liu, H. L., \& Chen, C. (2015). A comparative study of foreign language anxiety and motivation of academic- and vocational track high school students. English Language Teaching, 8(3), 193-204.

MacIntyre, P. D., \& Charos, C. (1996). Personality, attitudes, and affect as predictors of second language communication. Journal of Language and Social Psychology, 15, 3-26.

MacIntyre, P. D., Baker, S. C., Clement, R., \& Donovan, L. A. (2002). Sex and age effects on willingness to communicate, anxiety, perceived competence, and L2 motivation among junior high school French immersion students. Language Learning, 52(3), 537-564.

MacIntyre, P. D., \& Gardner, R. (1989). Anxiety and second language learning: Toward a theoretical clarification. Language Learning, 39, 251-275.

MacIntyre, P. D., \& Gardner, R. C. (1991). Methods and results in the study of anxiety and language learning: A review of literature. Language Learning, 41, 85-117.

Madran, D. (2006). Üniversite İngilizce hazırlı öğrencilerinin başarı güdüsü düzeylerinin başarıları üzerine etkileri. Unpublished master's thesis, Dokuz Eylül University, İzmir, Turkey.

Mesri, F. (2012). The relationship between gender and Iranian EFL leraners' foreign langauge classroom anxiety. International Journal of Academic Research in Business and Social Sciences, 2(6). $147-154$.

Nyikos, M. (1990). Sex related differences in adult language learning: Socialization and memory factors. The Modern Language Journal, 74(3), 273-286.

Oğuz, A., \& Akkaş Baysal, E. (2015). Ortaöğretim öğrencilerinin İngilizce öğrenme kaygıları ile İngilizce özyeterlik inançlarının incelenmesi. Eğitim ve Öğretim Araştırmaları Dergisi, 4(3), 107-117.

Öner, G., \& Gediklioğlu, T. (2007). Ortaöğretim öğrencilerinin İngilizce öğrenimlerini etkileyen yabanc1 dil kaygısı. Gaziantep Üniversitesi Sosyal Bilimler Dergisi, 6(2), 67-78. 
Özdinç Delbesoğlugil, A. B. (2013). As predictors of academic success in EFL classrooms, selfregulation, self-esteem and attitude (A case study). Unpublished master's thesis, Gaziantep University, Gaziantep, Turkey.

Özer, S., \& Y1lmaz, E. (2016). Students' attitudes towards vocational foreign language course. International Journal of Contemporary Educational Research, 3(2), 55-64.

Özer, S. (2016). Düşünme stillerine göre farklılaştırılmış öğretim etkinliklerinin öğrencilerin erişilerine, mesleki yabancı dil dersine yönelik tutumlarına ve ögrenilenlerin kalıcıllğına etkisi. Unpublished doctoral dissertation, Necmettin Erbakan University, Konya, Turkey.

Özer, S., \& Y1lmaz, E. (2018). The effect of thinking-style-based differentiated instruction on achievement, attitude and retention. Kastamonu Ë̆itim Dergisi, 26(1), 11-20.

Özer, S. (2018). A qualitative study to determine expectations of students studying at a faculty of tourism from vocational English course. International Journal of Progressive Education, 14(4), 15-25.

Özsoy, S., \& Özsoy, G. (2013). Eğitim araştırmalarında etki büyüklüğü raporlanması. İlköğretim Online, 12(2), 334-346.

Özütürk, G., \& Hürsen, Ç. (2013). Determination of English language learning anxiety in EFL classrooms. Procedia-Social and Behavioral Sciences, 84, 1899-1907.

Pineda, A. S. (2011). Attitude, motivation, and English language learning in a Mexican college context. Unpublished doctoral dissertation, The University of Arizona, Tucson, Arizona, USA.

Sahabani, M. B. (2012). Levels and sources of language anxiety and fear of negative evaluation among Iranian EFL learners. Theory and Practice in Language Studies, 2(11), 2378-2383.

Soleimani, H., \& Hanafi, S. (2013). Iranian medical students' attitudes towards English language learning. International Research Journal of Applied and Basic Sciences, 4(12), 3816-3823.

Spielberger, C. D. (1983). Manual for the state-trait anxiety inventory. Palo Alto, CA: Consulting Psychologists Press.

Sümer, N. (2000). Yapısal eşitlik modelleri: Temel kavramlar ve örnek uygulamalar. Türk Psikoloji Yazıları, 3(6), 49-74.

Tabachnick, B. G., \& Fidell, L. S. (2007). Using multivariate statistics (5th ed.). New York: Allyn and Bacon.

Temur, M. (2013). A study on determining the attitudinal and motivational levels of compulsorily and voluntarily students of English preparatory higher school at Inönü University. Unpublished master's thesis, Kafkas University, Kars, Turkey.

Tetik, N. (2016). Tourism guidance students' attitudes towards the English language course. International Journal of Education and Research, 4(3): 271-284.

Tosun, B. (2018). Oh no! Not ready to speak! An investigation on the major factors of foreign language classroom anxiety and the relationship between anxiety and age. Journal of Language and Linguistic Studies, 14(1), 230-241.

Tunçer, M., \& Doğan, Y. (2015). Hazırlık sınıfı öğrencilerinin yabancı dil ders kaygıları ve akademik öz-yeterlikleri arasındaki ilişki. Dil ve Edebiyat Eğitimi Dergisi, 14, 153-167.

Wang, J. R. (2011). Foreign language classroom anxiety and English academic performance among medical university students in Taiwan. Unpublished doctoral dissertation, La Sierra University, California, USA. 
Wang, T. (2010). Speaking anxiety: More of a function of personality than language achievement. Chinese Journal of Applied Linguistics, 33(5), 95-109.

Y1lmaz, E. (2013). Lise öğrencilerinin İngilizce dersi motivasyon düzeylerinin ve motivasyon tiplerinin belirlenmesi. Karaelmas Journal of Educational Sciences, 1, 1-10.

\section{Turizm fakültesi öğrencilerinin mesleki İngilizce dersine yönelik tutum, motivasyon ve kaygı düzeylerinin incelenmesi}

\section{$\ddot{\mathbf{O} z}$}

Bu çalışmanın amacı, turizm fakültesi öğrencilerinin mesleki İngilizce dersine yönelik tutum, motivasyon ve kaygı düzeylerinin incelenmesidir. Çalışmada, nicel araştırma yöntemi ve tarama modeli kullanılmıştır. Araştırmaya bir devlet üniversitesinin turizm fakültesinde öğrenim gören ve mesleki İngilizce dersini alan 325 öğrenci gönüllü olarak katılmıştır. Araştırmada, Mesleki İngilizce Dersine Yönelik Tutum Ölçeği, Motivasyon Ölçeği ve Yabancı Dil Kayg1 Ölçeği kullanılmıştır. Araştırma bulgularına göre, öğrencilerin mesleki İngilizce dersine yönelik tutumlarının ve motivasyonlarının "Katılıyorum" düzeyinde, kaygılarının ise "Kısmen Katılıyorum" düzeyinde olduğu tespit edilmiştir. Öğrencilerin mesleki İngilizce dersine yönelik tutum, motivasyon ve kaygı düzeylerinin yaş değişkenine göre farklı1ık göstermediği sonucuna ulaşılmıştır. Öğrencilerin öğrenim gördüğü bölümleri, başarı notları ve ders dışı ders ile ilgilenme süresi açısından mesleki İngilizce dersine yönelik tutum, motivasyon ve kaygı düzeyleri arasında anlamlı bir fark olduğu anlaşılmıştır. Öğrencilerin mesleki İngilizce dersine yönelik tutum ve motivasyon düzeyleri arasında cinsiyet açısından anlamlı fark olmadığı ancak kaygı düzeyleri arasında kız öğrenciler lehine fark olduğu görülmüştür. Öğrencilerin turizm deneyimi açısından mesleki İngilizce dersine yönelik tutum ve kaygı düzeyleri arasında anlamlı fark olmadığı fakat motivasyon düzeyleri arasında anlamlı bir fark olduğu tespit edilmiştir.

Anahtar sözcükler: Turizm fakültesi; mesleki İngilizce dersi; tutum; motivasyon; kayg1

\section{AUTHOR BIODATA}

Dr. Selda Özer majored in English Language Teaching and got her B.A. degree from Hacettepe University. She received her M.A. degree in Curriculum and Instruction from Erciyes University and her PhD degree in Curriculum and Instruction from Necmettin Erbakan University. She is currently a lecturer and teaches English at School of Foreign Languages, Nevsehir Hacı Bektaş Veli University, Turkey. She worked as a teacher of English at a governmental primary school in Ankara from 2002 to 2004. She is interested in curriculum and instruction, English language teaching, specifically teaching vocational English. 